\title{
New and Renewable Energy Policy in Developing Indonesia's National Energy Resilience
}

\author{
Sekar Anggun Gading Pinilih ${ }^{1 *}$ and Wiana Laelaputri Chairunnisa ${ }^{1}$ \\ ${ }^{1}$ Faculty of Law, Diponegoro University, Semarang-Indonesia
}

\begin{abstract}
This study aims to discuss new and renewable energy policies as an effort to build national energy security. Research methods use legal research that searches from various perspectives. The implementation of analysis, using the method of regulatory and focus on energy, generally has many impacts. First, the policy on the use of new and renewable energy aims to prepare the carrying capacity of national energy security. Implementation this policy has not been fully implemented because there are still many obstacles faced. Second, the use of new energy and renewable energy as an effort to build national energy security in Indonesia is still not optimal. Even though Indonesia is blessed with abundant natural and energy resources in all its regions and the need for new and renewable energy as the future fate of energy security in the unitary state of the Republic of Indonesia for people's welfare as a step to reduce the increase in consumption of fossil-based energy.
\end{abstract}

Keywords: New and Renewable Energy; Policy; Energy Security.

\section{Introduction}

In its development, energy sources are needed in meeting all human needs. Energy sources must also be maintained. Throughout history, humans have made many discoveries using energy. Before 1850, wood was the main source of fuel for heating, cooking and producing steam to drive steam engines on trains. Other energy sources are water, wind, coal, kerosene, and natural gas production. Natural gas was used since 500 $\mathrm{BC}$ by Chinese. They discovered that natural gas leaked from the ground through bamboo and was used as a gas pipe used to boil sea water to remove salt. Around 1816 natural gas was used to produce coal, and was first used to turn on street lighting in Baltimore, Maryland. From around 1850-1945, coal was the main fuel source. Meanwhile, wood is still an important energy source for heating and natural gas for lighting, but the use of water energy and wind starts to decrease. Starting in the 1900s, oil and gas became our main fuel source [1].

Indonesia is blessed with abundant natural resources including energy that spreads throughout Indonesia. Management of this natural wealth is a mandate of Article 33 paragraph 3 of the 1945 Constitution of the Republic of Indonesia which is used for the greatest prosperity of the people of Indonesia. To be able to optimize revenue from the exploitation of these resources, it is necessary to prevent potential waste especially on energy resources. Indonesia's dependence on fossil fuels is huge and this is inseparable from everyday community activities such as cooking, transportation and lighting. This continuous use, in 2030 the availability of fossil energy in Indonesia will not meet national needs. Indonesia's position is significant to further ASEAN cooperation in the energy sector. Accounting for almost $40 \%$ of ASEAN energy consumption, Indonesia is the largest energy consuming country in the region. According to the 5th ASEAN Energy Outlook which was launched by ACE during the 34th ASEAN Minister of Energy Meeting (AMEM) with the presence of the Philippine Secretary of Energy, Alfonso G. Cusi [2]. Global warming becoming today's reality, many countries have implemented various programs for reduction of greenhouse gas emissions, development of green technologies, or replacement of fossil fuels with eco-friendly substitutes. Governmentdriven stimulation of the production and consumption of renewable energy-typically, wind power, solar energy, and biofuels-has become part of national climate mitigation agendas [3].

The International Energy Agency (IEA) defines energy security as the availability of uninterrupted energy sources at affordable prices. Furthermore, the measure used to assess a country is said to have energy security if it has an energy supply for 90 days of oil equivalent import needs. During the period of 2006 to 2010, the composition of oil declined slightly from $51.3 \%$ to $47.1 \%$ or decreased by around $1 \%$ per year. However, the trend

${ }^{*}$ Corresponding author: sekar anggun $@$ live.undip.ac.id 
of decreasing the portion of oil stalled and returned to increase again in 2011 to $47.7 \%$ of the national energy mix. This condition indicates that the steps taken by the government are not effective and there is an increased risk of energy security [4]. The Indonesian government still finds many obstacles in maintaining national energy security. There are still many policies that are not working properly and certainly not optimal, even though there are targets in maintaining national energy.

Table. 1. Target of National Energy Policy (KEN) and Target of Energy Mix (Source: RUEN 2015 - 2050)

\begin{tabular}{|c|c|c|c|c|c|c|}
\hline No. & $\begin{array}{c}\text { KEN } \\
\text { Target }\end{array}$ & Unit & $\begin{array}{l}2 \\
0 \\
1 \\
5\end{array}$ & $\begin{array}{l}2 \\
0 \\
2 \\
0\end{array}$ & 2025 & 2050 \\
\hline 1. & $\begin{array}{l}\text { Primary } \\
\text { energy } \\
\text { supply }\end{array}$ & $\begin{array}{c}\text { MTO } \\
\text { E }\end{array}$ & & & $>400$ & $>1.000$ \\
\hline 2. & $\begin{array}{l}\text { Energy } \\
\text { Mix } \\
\text { Target }\end{array}$ & & & & & \\
\hline & a. EBT & $\%$ & & & $>23$ & $>31$ \\
\hline & $\begin{array}{l}\text { b. Crude } \\
\text { Oil }\end{array}$ & $\%$ & & & $<25$ & $<20$ \\
\hline & c. Coal & $\%$ & & & $>30$ & $>25$ \\
\hline & $\begin{array}{l}\text { d. Natural } \\
\text { Gas }\end{array}$ & $\%$ & & & $>22$ & $>24$ \\
\hline
\end{tabular}

To achieve the national energy policy targets and energy mix targets, it is necessary to have a national energy policy from a good government so that energy resources in Indonesia can be developed and utilized as well as possible in the long term to support development especially in the use of new and renewable energy based on one of the regulations is Government Regulation No. 79 of 2014 concerning National Energy Policy. In this connection with this description, this research will focus on the Policy for the Use of Renewable Energy as an Effort to maintain National Energy Resilience. The theme will focus on deepening the related material: 1). What is the government policy related to the use of new and renewable energy in order to prepare the carrying capacity of national energy security, 2). How also the use of new and renewable energy as part of efforts to encourage national energy security in Indonesia.

\section{Material and method}

This research is a legal research looking from various perspectives in all aspects. The implementation of analysis, using normative approach with focus on Energy Regulation which in the fact that regulation generally has many impacts. Normative approach is using by analyze the regulations and the other materials are from journal, books and valid data as references. This approach aims to know whether the regulations and its implementation in Indonesia is effective and efficient to reach the target or even not.

\section{Result and discussion}

\subsection{Implementation of New and Renewable Energy Policies in Building National Energy Security}

In accordance with Article 33 paragraph 3 of the 1945 Constitution of the Republic of Indonesia which states that the earth and water and natural resources contained therein are controlled by the state and are used for the maximum benefit of the people, therefore national energy utilization must also be aimed at for people's welfare. Government Regulation No. 79 of 2014 concerning National Energy Policies, in the use of new and renewable energy is a top priority and fossil-based energy such as diesel is minimized. The development of new and renewable energy as a substitute for fossil energy is carried out in stages. Various regulations to regulate it continue to be built along with regulating tariffs to be able to meet energy needs to the maximum for some time to come. National energy policy is a government policy related to energy so that all energy sources in Indonesia can be utilized and managed as well as possible in the long term and certainly for fossil-based energy in its use can be saved and more efficiently used to remember fossil energy if not handled well and continuously exploited will run out with a short time. The development and utilization of energy is still directed at energy management in a efficient and efficient manner and is based on a comprehensive energy policy and by taking into account the increasing need and ability to supply energy strategically in the long term [5]. This energy management policy is also based on the principle of fairness, sustainability and environmental insight in order to create energy independence and national energy security to support Sustainable National Development. In the Presidential Regulation of the Republic of Indonesia No. 22 of 2017 concerning The National Energy General Plan, we know that there is a need for implementation in national energy policies to achieve the target. In its implementation, the steps taken by the government have not been effective and this increases the risk of energy security.

Indonesia is the oldest oil producer in the world but with a relatively small reserve compared to its many energy needs. Since 2004, Indonesia has become a net oil importing country, which means that oil imports are greater than oil exports. This is not only caused by economic growth but also due to population growth which has increased consumption. The phenomenon of falling world oil prices, from US \$ 100 per barrel in 2014 to below US \$ 35 per barrel at the end of 2015 . To the 
best of our knowledge, energy is conserved, so the total annual consumption of a nation, a factory or a household must be equal to its total annual supply [6]. Indonesia is a vast country and has the potential of abundant energy sources throughout its territory, especially in new and renewable energy. But the vastness of the Indonesian state is one of the obstacles in building energy infrastructure to realize energy needs evenly throughout the Indonesian territory. Though this new and renewable energy can be the best solution in order to support national energy security especially in reducing the use of fossil energy such as petroleum and coal. Being an obstacle in its implementation is the absence of incentives for the utilization of new and renewable energy and not yet maximized price policies.

The use of renewable energy will still face obstacles as long as the production costs are higher than the use of fossil energy. The price of new and renewable energy has not been competitive because one of the factors is the existence of subsidies for fuel oil and electricity. New and renewable energy technologies affect the price because the technology used is still expensive. So that new and renewable energy is still unable to compete with fossil energy. Even though oil fuel subsidies are also not yet on target. A good step to overcome this is to divert subsidies to fossil energy to subsidies for new and renewable energy. The low level of exploration and exploitation activities and government involvement are a challenge in the development of energy resources that have not become development capital even though national energy policy stipulates that energy is a national development capital, no longer a foreign exchange earner (especially gas and coal are still the main commodity foreign exchange). The use of new and renewable energy in Indonesia is still relatively low.

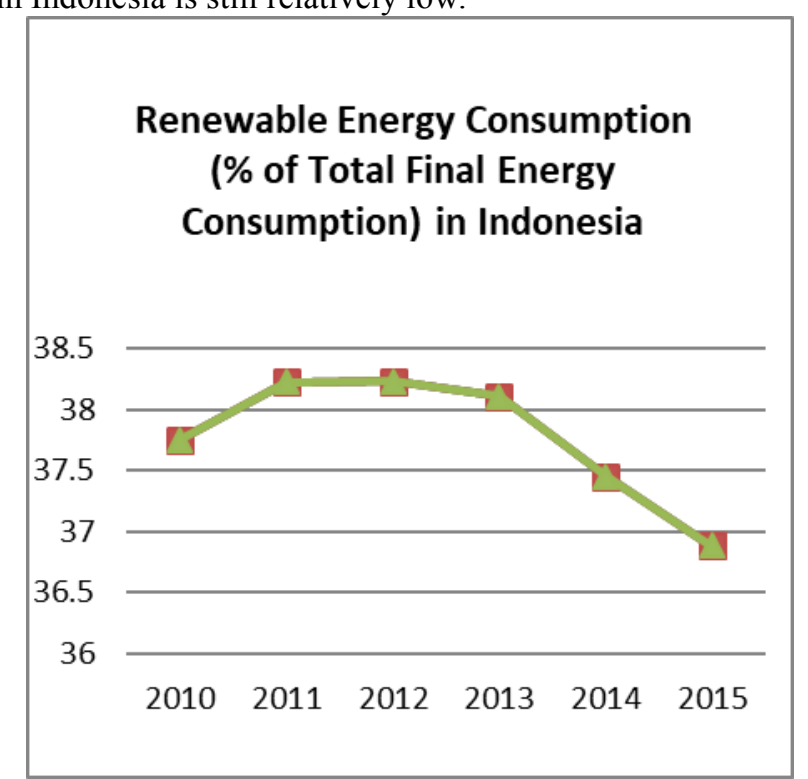

Fig. 1. Renewable Energy Consumption (\% of Total Final Energy Consumption) in Indonesia. (Source : World bank)
In licensing, there is still difficulty and lack of coordination between the central government and the regional government. For example, in the case of the central government, it has given support and permission, but the regional government as the regional authority according to the Regional Autonomy Law does not give permission. Though the government can act as a driver to determine the direction of policy related to the management of renewable energy potential. The Indonesian government through the Minister of Energy and Mineral Resources has realized the consistency of its policies by banning the construction of power plants using fuel oil. The aim is to save on fuel oil use and reduce energy subsidies [7]. If a peek at the development of the German State, Germany prefers to concentrate on developing renewable energy technologies as an effort to secure its energy supply, also contributes to the creation of Sustainable Development. After the oil crisis in 1973 Germany changed its energy policy strategy by investing the national budget. The budget is used for research and development of renewable energy technologies, namely: solar and turbine power [8]. Brazil is also successful in developing the best new and renewable energy in the world whose development began since oil cirisis in 1975 . The country's success in reducing consumption in fossil energy, it must be realized in Indonesia in the context of national energy security, especially in new and renewable energy.

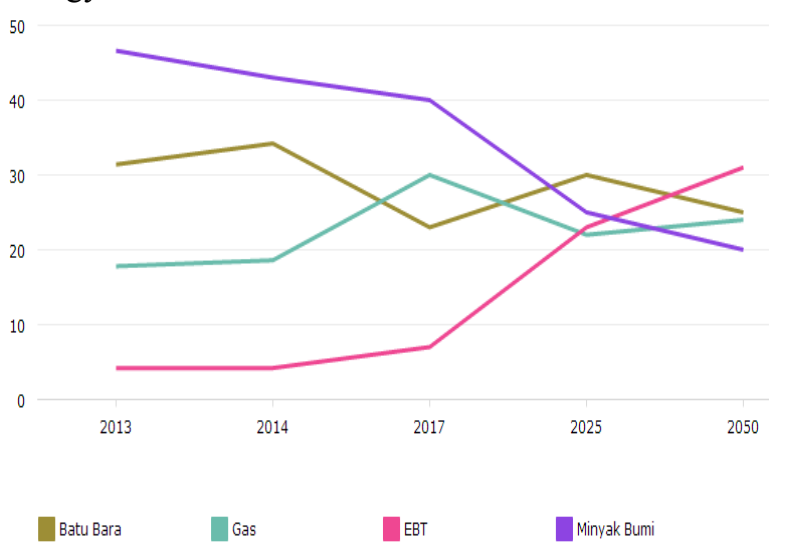

Fig. 2. Indonesian Energy Mix (2013-2050) (Source: databoks.co.id)

\subsection{Use of New and Renewable Energy}

In 2018, the government targets oil production of around 800 thousand barrels per day. However, until the end of July 2018, data from the Ministry of Energy and Mineral Resources showed that the average oil production was still around 773 thousand barrels. The amount of production is far below last year which is still at 949 thousand barrels per day [9]. This is what happens, oil production continues to decline while the consumption of fuel oil in Indonesia actually increases with population growth and the use of the population will be vehicles that 
increase the number of population of motorized vehicles both cars and motorcycles. Increasing energy demand dominated by non-renewable fossil energy is certainly not environmentally friendly which causes environmental problems such as environmental pollution, global warming and others. The pattern of society in its use is also still very wasteful and inefficient.

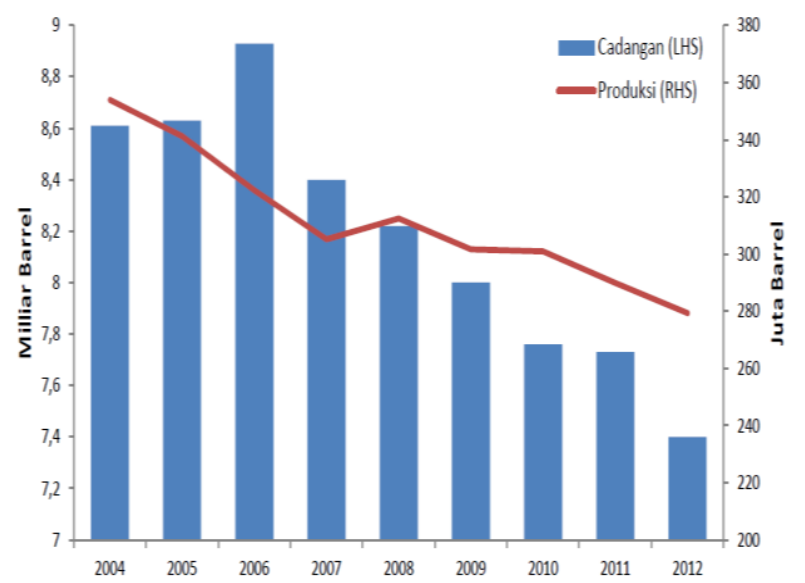

Fig. 3. Development of Indonesian Crude Oil Reserves and Production (Source: Ministry of Energy and Mineral Resources, data processed)

Efforts to reduce Indonesia's dependence on fossil fuels that cannot be renewed and are increasingly depleted and even leading to extinction, it is necessary to use new and renewable energy which is the best alternative. It is this new and renewable energy that is the energy of the future as a substitute for energy sources that are currently used to fulfill energy. Potential development of various new energy and renewable energy Indonesia has the energy potential of various new and renewable energies that are quite large and spread in various regions, but until now the utilization is still very small [10]. This energy is one of the important factors in supporting all aspects of social, economic, and other aspects including the environment in realizing the Sustainable Development, which at present certainly lead to The 4th Industrial Revolution. The development of new and renewable energy is intended to be realized properly in achieving prosperity as stated in the Opening of the 1945 Republic of Indonesia's Constitution [11]. Technology in the utilization and management of new and renewable energy must support and certainly be environmentally friendly that can be used in various things such as electricity generation, lighting, transportation, and households for national energy security. The target of the installed capacity is the supply of new and renewable energy per cluster until 2025 according to what was presented by the organizing committee of the workshop from Indonesian Renewable Energy Society (METI), the Indonesian Geothermal Association (APO), and other groups.
Table. 2. The Target for Installed Capacity is The Supply of New and Renewable Energy in Indonesia per Energy Type until 2025

\begin{tabular}{|l|c|c|c|c|}
\hline $\begin{array}{c}\text { BBN } \\
\text { Energy } \\
\text { Type }\end{array}$ & $\mathbf{2 0 1 5}$ & $\mathbf{2 0 2 0}$ & $\mathbf{2 0 2 5}$ & $\begin{array}{c}\text { Poten } \\
\text { cy }\end{array}$ \\
\hline $\begin{array}{l}\text { Biodiesel } \\
\text { (KL) }\end{array}$ & $\begin{array}{c}1.700 .00 \\
0\end{array}$ & 5.784 .000 & $\begin{array}{c}16.371 .55 \\
9\end{array}$ & \\
\hline $\begin{array}{l}\text { Bioetanol } \\
\text { (KL) }\end{array}$ & $\begin{array}{c}1.12 .00 \\
0\end{array}$ & 3.624 .000 & 6.876 .055 & $\begin{array}{c}49.81 \\
0\end{array}$ \\
$\begin{array}{l}\text { Biomassa } \\
\text { (others) } \\
\text { (MW) }\end{array}$ & 590 & 710 & 870 & \\
\hline $\begin{array}{l}\text { Geotherm } \\
\text { al (MW) }\end{array}$ & 4.156 & 7.788 & 12.332 & 27.00 \\
\hline $\begin{array}{l}\text { Wind } \\
\text { (MW) } \\
\text { Sun(MW) }\end{array}$ & 85 & 128 & 256 & 9.290 \\
\hline $\begin{array}{l}\text { Small } \\
\text { PLTA } \\
\text { (MW) }\end{array}$ & 417 & 760 & 2.486 & \\
\hline $\begin{array}{l}\text { Big PLTA } \\
\text { (MW) }\end{array}$ & 6.069 & 8.940 & & 76.17 \\
\hline
\end{tabular}

Seeing other countries, in 2000 Germany began to develop biofuels as an action to reduce fossil fuel consumption by conducting policy interventions from farmer level to marketing, which were assisted by industry and scientists in synergizing. Besides that, the state must be present in order to manage and manage the production of natural resources including rare earth metals. Rare earth metals strongly support the efforts of the country to produce green energy economics [11]. Development of bioenergy as a renewable alternative fuel is considered suitable to overcome energy problems because it is environmentally friendly, biodegradable, and able to eliminate the greenhouse effect. Bioenergy can be obtained quite simply by cultivating biofuelproducing plants and raising livestock. Along with the development of science and technology, bioenergy is transformed into more modern forms such as bioethanol, PPO or SVO, biogas and biodiesel. Fossil energy is indeed a driver of economic growth to date, but it is hoped that in its development it will become new and renewable energy to reduce Indonesia's dependence on fossil energy, where new and renewable energy has many advantages and benefits when used rather than fossil energy.

\section{Conclusion}

Based on the overall description, it can be concluded that: First, government policies related to new and renewable energy need to be fully utilized by the government in developing Indonesia's national energy 
security, and secondly, the use of new energy and renewable energy needs to be developed from all aspects, especially the technology. This new and renewable energy is the best solution in overcoming environmental problems and for Indonesia's national energy security due to its environmental friendliness and renewability, considering that fossil energy if used continuously will run out. Efforts to explore and exploit new and renewable energy are currently not optimal, even though Indonesia has great potential as an effort to reduce consumption in fossil energy.

\section{References}

1. Sutarno, Sumber Daya Energi, 1st ed. Graha Ilmu (2013)

2. "No Title." Online.. Available: www.aseanenergy.org/articles/indonesias-energypolicy-strategy-towards-modern-greeneconomy/indonesia's energy policy strategy: towards modern \& green economy

3. S. Shadikhodjaev, Renewable Energy and Government Support: Time to 'Green' the SCM Agreement?, World Trade Rev. 3(14), 479 (2015)

4. R. Azmi, A. Hidayat, Ketahanan Energi: Konsep, Kebijakan Dan Tantangan Bagi Indonesia, Available: www.Kemenkeu.Go.Id/Sites/Default/ Files/Energy security.pdf

5. Departemen Penerangan RI, Panas Bumi Mendukung Kebijaksanaan Energi di Indonesia, Jakarta (1995)

6. J. Ramage, Energy A Guidebook, Oxford (1932)

7. N. Hendri, Implementasi Sustainable Developmet Goals (SDGs) Dalam Pengelolaan Potensi Energi Terbarukan Untuk Mewujudkan Ketahanan Energi Di Indonesia (2017)

8. P.D.A. Rani, Kepentingan Bergabungnya Indonesia Dalam Asosiasi International Energy Agency (IEA), University Of Muhammadiyah Malang (2017)

9. "No Title." Online.. Available: www.bppt.go.id/teknologi-informasi-energi-danmaterial/3296-bppt-indonesia-darurat-energi.

10. M.K.K.E, S.D. Mineral, www.esdm.go.id/assets/media/content/fix2_jurnal_e nergi_edisi_2_17112016(1).pdf, J. Energi 2(20) (2016)

11. M. A. Solechan, R. Saraswati, P. Suharso, Suhartoyo, B. Ispriyarso, The New Renewable Energy Consumption Policy of Rare Earth Metals to Build Indonesia's National Energy Security, E3S Web of Conferences 68, 7 (2018) 